\title{
Nomenclature ANd taxonomy of Philodendron hastatum K. Koch \& Sello
}

Cássia M. Sakuragui ${ }^{1} \&$ Simon J. Mayo ${ }^{2}$

\begin{abstract}
(Nomenclature and taxonomy of Philodendron hastatum K. Koch \& Sello) The paper discusses the taxonomy and nomenclature of Philodendron hastatum and aims to clarify the status of some other names often used to name specimens with similar leaf blade shape. A description of the species is provided based on the study of herbarium material.
\end{abstract}

Key-words: Araceae, Philodendron hastatum, nomenclature, typification.

Resumo

(Nomenclatura e taxonomia de Philodendron hastatum K. Koch \& Sello) O trabalho discute a taxonomia e nomenclatura de Philodendron hastatum e objetivou esclarecer o status de outros nomes freqüentemente utilizados para nomear espécies com morfologia foliar similar. São fornecidas descrição morfológica e figura da espécie baseadas no estudo de materiais de herbário.

Palavras-chave: Araceae, Philodendron hastatum, nomenclatura, tipificação.

\section{INTRODUCTION}

Philodendron hastatum, like many other Philodendron species, typically has great vegetative morphological variation, particularly in leaf shape. This species, however, shows two remarkable characteristics in the leaf blade leaf: the lobes of the posterior division are extrorse an arcuate sinus, and the anterior region is very elongated, at least three times longer than the length of the posterior lobes. It occurs in south-eastern Brazil (Rio de Janeiro and Minas Gerais states), growing in humid forests as a hemiepiphyte.

The morphological variation of the leaves, from juvenile to adult stages, makes specimens identification difficult, especially sterile ones. The major problem, however, seems to be the confusion among the different names that may appear on the labels indiscriminately, such P. hastifolium (of various authors) and P. elongatum Engler.

The present paper aims to clarify some of the problems linked to the name $P$. hastatum C. Koch \& Sello and to suggest a specimen for the neotypification of this name.

\section{Results and Discussion}

Philodendron hastatum K. Koch \& Sello in Index sem. hort. berol. 1854. Appendix: 7 (1854/1855). Neotype here designated: "Hort. Schoenb. Hb. Schott 1859", specimen of a cultivated plant named as "Philodendron hastatum C. Koch" (in H. W. Schott's handwriting) with an additional label by $\mathrm{N}$. E. Brown 1878: "Philodendron hastatum C. Koch. Compared with type in C. Koch's herbarium by N.E. Brown 1878" (K!).

Philodendron elongatum Engl. In: Martius, Flora brasiliensis 3(2): 160. 1878.

Neotype: as for P. hastatum K. Koch \& Sello

Philodendron hastifolium sensu Engl. In: Martius, Flora brasiliensis 3(2): 162.1878 \& in A. \& C. de Candolle, Monogr. Phanerog. 2: 414. 1879, non Regel (1857).

Philodendron hastifolium Regel ("hastaefolium"). In Gartenflora 5: 131, t. 159 (1857). Type: "Ex horto bot. Petropolitano. 60.90 Philodendron hastifolia Regel vo [illegible] Rgl.” (LE!)

Fig. 1.

Artigo recebido em 09/2004. Aceito para publicação em 02/2005.

${ }^{1}$ Universidade de Maringá. Depto. Biologia - CCB. Av. Colombo 5790, 87020-900 Brasil. e-mail: cmsakura@uem.br ${ }^{2}$ Royal Botanic Gardens, Kew - Herbarium. Richmond, Surrey TW9 3AE. United Kingdom. 
Hemiepiphyte. Stem: internodes $1.5-8$ $\mathrm{cm}$ long. Leaf: prophyll $18-25.5 \mathrm{~cm}$ long, pale green, glossy; petiole $13.5-46 \mathrm{~cm}$ long; blade $20-45 \times 7-15 \mathrm{~cm}$, narrowly ovate to triangular ovate, chartaceous, dark green on the adaxial surface, pale green on the abaxial surface, semiglossy to glossy, rounded to subacute at apex, sagittate at base; anterior lobe 25.5-32 × 7-15 cm; posterior lobes 5$11 \times 6-10 \mathrm{~cm}$; sinus arcuate; basal veins 3 per side, with 1 free to the base, 2 coalesced for 6-8 $\mathrm{mm}$; posterior rib naked for 3-4 cm; primary lateral veins 6-7 per side; minor veins inconspicuous. Inflorescence: one per axil, peduncle 5.5-4.5 cm long; spathe 8.5-12.5 cm long, ovate, white externally, greenish cream internally; spadix $7.5-12 \mathrm{~cm}$ long, staminate zone 3-6 cm long, cream, sterile zone $0.5-1 \mathrm{~cm}$ long, white, pistillate zone $3.5-$ $4.5 \mathrm{~cm}$ long, greenish. Flower: stamen 1-1.2 $\times 0.8-1 \mathrm{~mm}$; staminode $2-4 \times 1-2 \mathrm{~mm}$; gynoecium 1-1.5 × $0.8-1 \mathrm{~mm}$, ovate, ovary 5-6 locular, 2-5 ovules per locule, placentation subbasal. Berry (young): 1.5-2.5 $\times 1-1.5 \mathrm{~mm}$, pale green, pear shaped; seed $0.8-1 \mathrm{~mm}$ long, ellipsoid.

Specimens examined: BRAZIL. MINAS GERAIS: Juiz de Fora, 16.IX.1972, Kreiger \& Urbano 11796 (CESJ, SPF); l.c. 14.VIII.1970, Krieger 9179 (CESJ, SPF); RIO DE JANEIRO: Corcovado, Meso do Inperador, 10.IX.1958, Pereira et al. 4296 (RB); Guanabara, 1.XII.1971, Sucre 8024 (RB); l.c. 22 .X. 1969, Sucre 6118 (RB); Floresta da Tijuca, 31.VIII.1958, Pabst 4541 (B); Nova Iguaçú, Distrito de Tinguá, 25.XI.1992, Nadruz et al. 819 (RB).

Cultivated material: BRAZIL. RIO DE JANEIRO: Jardim Botânico do Rio de Janeiro, RB 94024; l.c. RB 94831; l.c. RB 95730.

The date of publication of the original description of P. hastatum K.Koch \& Sello is not completely clear. Some species described in the same work have comments on flowering times being in November, suggesting that publication could have occurred at the end of 1854 or beginning of 1855 . Schott (1856) cited "1854/1855" but in later work, e.g. (Schott

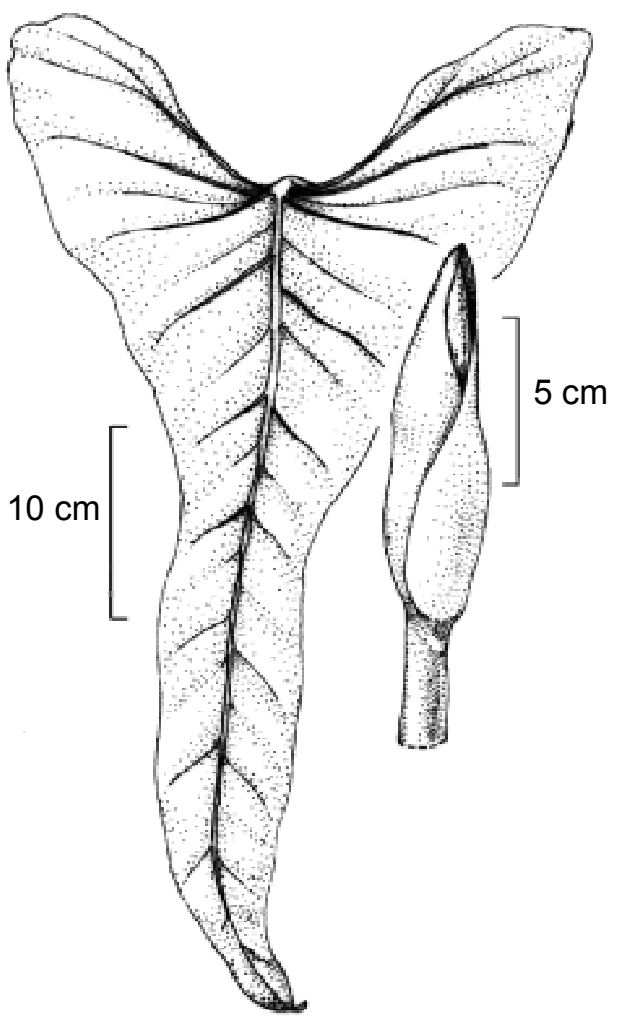

Figure 1 - Philodendron hastatum: leaf lamina and inflorescence (drawing from dried material Krieger 9179)

1860), he cited just " 1854 ".

The type material must have been a cultivated plant at the Berlin Botanical Garden since the species was described in the Appendix of the Garden's annual seed catalogue. What is the evidence for the existence of a type specimen? Among the photographs of the Chicago Field Museum collection, "Types of the Berlin Herbarium", number 12228 could represent type material. This specimen, no longer to be found at Berlin (B), was probably destroyed during the Second World War. There were two labels: on one was written "Philodendron simsii hort. Berol 53" in unknown handwriting. Koch added "Hort." after the name "Philodendron simsii" and separately wrote "Philodendron hastifolium C. Koch et Sello". The other label was printed: "Museum botanicum Berolinense." and included in Engler's hand:- 
"Philodendron hastifolium C. Koch et Sello Engler". However, on this last label, the epithet is corrected (a line through it) and a replacement epithet "hastatum" added above also in Engler's hand. It should be noted that Koch's original description mentioned " $P h$. simsii hortor." as a "synonym" of $P$. hastatum. Therefore it is very likely that this material was used for the original description. A problem with this specimen is that Koch's own annotation gives the name $P$. hastifolium whereas the name he published was $P$. hastatum. What probably occurred was that Koch named the specimen " $P$. hastifolium" while examining the material but decided to use the epithet "hastatum" in the publication later on and never went back to correct the name on the specimen label. If this doubtful point is ignored, it is reasonable to accept the photograph as a representative part of the protologue of $P$. hastatum K.Koch \& Sello; there is little doubt that it is of an authentic Koch specimen, no longer in existence. As shown below, it seems clear that the specimen represents a juvenile plant and that Koch's complete type material included other mature specimens of which not even photographs survive.

Another specimen that can be connected to the protologue exists at the Kew Herbarium $(\mathrm{K})$, consisting of juvenile leaves from a plant grown at Kew. One leaf has the following annotation by N. E. Brown (a nineteenth century Kew botanist and aroid specialist who personally studied K.Koch's herbarium collection): "Philodendron hastatum C. Koch! Compared with type in C. Koch's Herbarium by N. E. Brown 1878..." It is quite likely that this plant was sent to Kew by from Berlin by Koch, which would explain why Brown took the trouble to compare it with Koch's own herbarium material. Brown comments further on this sheet that the leaf of the Kew plant is a juvenile, matching juvenile leaves in Koch's herbarium. But he also comments that the leaves of Koch's flowering stage specimens are distinctly sagittate-hastate. At this point we may introduce a third specimen, the Kew sheet we have selected as neotype for $P$. hastatum. This fertile specimen has a fully sagittate-hastate leaf and is from a plant grown by Schott at the Schoenbrunn Palace Gardens near Vienna and identified by him as $P$. hastatum K.,Koch \& Sello; this identification alone is enough to suggest the plant may have been grown on from a cutting of Koch's original plant sent from Berlin to Schott. In any case, we know that N. E. Brown compared it with Koch's type material and confirmed the determination as $P$. hastatum K., Koch \& Sello. Based on Brown's testimony we can therefore conclude that Koch's mature specimens of $P$. hastatum, of which none survive, correspond to the Schott specimen at Kew.

Engler $(1878,1879)$ took up the name "P. hastifolium K. Koch \& Sello" in error for P. hastatum K. Koch \& Sello, and included $P$. hastaefolium Regel as a synonym. At the same time he excluded Schott's concept of $P$. hastatum, using the latter as the basis for the name $P$. elongatum Engl., of which more below. Our interpretation is that, for whatever reason, Engler separated the juvenile and mature forms of $P$. hastatum K.Koch \& Sello into one species with weakly sagittate-hastate leaves (P. hastifolium) and another with strongly sagittate-hastate leaves ( $P$. elongatum).

Later publications further confused matters. Engler (1899) resurrected the names $P$. hastatum K. Koch \& Sello and $P$. hastaefolium Regel as separate species. $\mathrm{He}$ then described a completely different Ecuadorian species with the name $P$. hastatum Engl., later renamed by Krause (1913) as P.subhastatum Engl. ex K. Krause.

A key point in deciding that Engler made a mistake in describing $P$. elongatum concerns the issue of whether Schott's and Koch's concepts of $P$. hastatum were or were not the same. Engler, right from his first publication on the subject (Engler 1878), separated the two. 
In his original description of $P$. elongatum, he cites: "Philodendron hastatum Schott Syn.Ar. 101, Prodr. 279, non C. Koch. ... Habitat in Brasilia, loco accuratius non cognito: Schott". Engler evidently considered that Schott's and Koch's concepts of $P$. hastatum were different. There is an impressive contrast between the specimen pictured in Field Museum photo no. 12228 (Engler's $P$. hastatum; our $P$. hastatum with juvenile leaves) and the Schott specimen at Kew (Engler's P. elongatum, our P. hastatum with mature leaves). However an important corroboration that C. Koch's and Schott's concepts of $P$. hastatum were the same is given by comparing Koch's original description of the species and Schott's drawings of $P$. hastatum (Icones Aroideae numbers 2572, 2573, 2574, 2690, 2691, 2692, Schott, 1984), which match very well.

In conclusion, we disagree with Engler that Koch's and Schott's concepts of $P$. hastatum were different. We follow N. E. Brown in proposing that Koch's mature specimens of $P$. hastatum, of which none survive nor of which we have any illustrations, corresponded to the Schott specimen of $P$. hastatum at Kew. In the absence of any authentic specimens of Koch, we therefore propose to resolve this question by neotypifying the names $P$. hastatum K.Koch $\&$ Sello and $P$. elongatum Engl. on this same Schott specimen, at the same time sinking $P$. hastifolium Regel ("hastaefolium") once again, since it represents no more than a juvenile form.

\section{Literature Cited}

Engler, A. 1878. Araceae. In Martius, C. P. F. von, Flora brasiliensis 3(2): 160-163. 1879. Araceae. In De Candolle, A. C., Monographiae Phanerogamarum 2: 414-415. (1899). Beiträge zur Kenntnis der Araceae IX. Bot. Jahrb. 26: 538.

Krause, K. 1913. Araceae-PhilodendroideaePhilodendreae-Philodendrinae. In A. Engler (ed.), Das Pflanzenreich 60 (IV.23Db): 86.

Regel, E. 1857 (“1856”). Index seminum quae hortus botanicus Imperialis Petropolitanus pro mutua commutatione offert. Accedunt animadversiones botanicae nonnullae. 8. Linnaea 28: 376.

Schott, H. W. 1856. Synopsis Aroidearum, p. 101. Typis congregationis mechitharisticae, Vienna.

. 1860. Prodromus systematis Aroidearum, p. 279. Typis congregationis mechitharisticae, Vienna.

1984. Icones Aroideae et Reliquiae. Microfiche edition, Index ed. D. H. Nicolson, 29p. IDC AG, Zug. 
